\title{
NON-SPECIFIC CONNECTIVE TISSUE DYSPLASIA - A RISK FACTOR FOR POSTOPERATIVE THROMBOSIS IN THE VENOUS SYSTEM OF LOWER EXTREMITIES
}

\section{NIESWOISTA DYSPLAZJA TKANKI ŁAZCZNEJ - CZYNNIK RYZYKA W PRZYPADKU POOPERACYJNEJ ZAKRZEPICY UKŁADU ŻYLNEGO W KOŃCZYNACH DOLNYCH}

\author{
Ihor Venher $^{1(\mathrm{~A}, \mathrm{D}, \mathrm{G})}$, Sviatoslav Kostiv ${ }^{1(\mathrm{~B}, \mathrm{C}, \mathrm{E})}$, Inna Nenashko ${ }^{2(\mathrm{D}, \mathrm{F})}$
}

${ }^{1}$ I.Ya. Horbachevsky State Medical University of Ternopil, Ukraine

${ }^{2}$ Ternopil University Hospital, Ukraine

Authors' contribution Wkład autorów: A. Study design/planning zaplanowanie badań B. Data collection/entry zebranie danych C. Data analysis/statistics dane - analiza i statystyki D. Data interpretation interpretacja danych E. Preparation of manuscript przygotowanie artykułu F. Literature analysis/search wyszukiwanie i analiza literatury G. Funds collection zebranie funduszy
Tables: 2

Figures: 1

References: 7

Submitted: 13.08 .2015

Accepted: 25.01.2016

\begin{abstract}
Summary
Background. Deep vein thrombosis of lower extremities and pulmonary embolism have common pathogenic roots and are the most common cause of poor blood circulation. Several factors that contribute to the development of thrombosis in the venous system are identified and must be taken into consideration in the process of preparing for surgery.

Material and methods. 472 patients were examined and operated in departments of surgery of municipal institution of Ternopil regional council Ternopil University Hospital in 2010-2014. In the process of surgical treatment thromboprophylaxis was applied according to sectoral protocols [1].

Results. In postoperative period thrombotic process in the system IVC was diagnosed in 96 $(20.34 \%)$ patients. The incidence of postoperative thrombosis in the IVC system was directly related to the risk of the venous thromboembolic complications. dysplasia; in $27(45.1 \%)$ observations detected asthenic type of constitution, in 18 (36.6\%) - hypermorbid syndrome, in $31(57.7 \%)$ - varicose veins (class C1 - 27 cases, class C2 - 14 cases). In the laboratory study the indicators of metabolic products connective tissue level of total oxyproline exceeded the reference value at $41.77 \%(\mathrm{p}<0.001)$, free oxyproline - by $46.85 \%$ ( $\mathrm{p}<0.001)$, and bound oxyproline $31.71 \%(\mathrm{p}<0.001)$.

Conclusions. Established that non-specific connective tissue dysplasia can be significant risk factor for postoperative venous thrombosis in the system inferior vena cava.
\end{abstract}

Keywords: deep vein thrombosis, postoperative thromboembolism, connective tissue dysplasia

\section{Streszczenie}

Wprowadzenie. Zakrzepica żył głębokich dolnych kończyn oraz zatorowość płucna mają wspólne patologiczne podstawy i są częstszą przyczyną złego krążenia krwi. Kilka czynników wpływających na rozwój zakrzepicy w systemie żylnym zostało zidentyfikowanych, zatem należy brać je pod uwagę $w$ procesie przygotowawczym przed operacją.

Materiał i metody. 472 pacjentów przebadano i zoperowano w klinikach chirurgicznych jednostki miejskiej rady regionalnej Tarnopolu w Uniwersyteckim Szpitalu w Tarnopolu w latach 2010-2014. W trakcie leczenia chirurgicznego zastosowano profilaktykę przeciwzakrzepową zgodnie z protokołami sektorowymi [1].

Wyniki. W okresie pooperacyjnym zdiagnozowano proces zakrzepowy w systemie IVC $\mathrm{w}$ przypadku 96 pacjentów (20,34\%). Występowanie zakrzepicy pooperacyjnej w systemie IVC było bezpośrednio związane z ryzykiem komplikacji zakrzepowo-zatorowej, dysplazja; w przypadku 27 pacjentów (45.1\%) zaobserwowano asteniczny typ składu, w 18 przypadkach $(36.6 \%)$ - syndrom hiper-morbidowy, w przypadku 31 pacjentów (57.7\%) - żylaki kończyn dolnych (klasa C1 - 27 pacjentów, klasa C2 - 14 pacjentów). W badaniach laboratoryjnych wskaźniki produktów metabolicznych poziomu tkanki łącznej całkowitej oksoproliny przewyższają wartość referencyjną w 41.77\% ( $\mathrm{p}<0.001)$ pacjentów, wolnej oksoproliny - w 46.85\% ( $\mathrm{p}<0.001)$ przypadków, a związanej oksoproliny - w 31.71\% (p<0.001) przypadków.

Wnioski. Ustalono, że nieswoista dysplazja tkanki łącznej może być silnym czynnikiem ryzyka w przypadku pooperacyjnej zakrzepicy układu żylnego w kończynach dolnych.

Słowa kluczowe: głęboka zakrzepica żylna, pooperacyjna zakrzepica, dysplazja tkanki łącznej

Venher I, Kostiv S, Nenashko I. Non-specific connective tissue dysplasia - a risk factor for postoperative thrombosis in the venous system of lower extremities. Health Problems of Civilization 2016; 10(2): 51-54. doi: 10.5114/hpc.2016.59633.

Address for correspondence / Adres korespondencyjny: Sviatoslav Kostiv, I.Ya. Horbachevsky State Medical University of Ternopil, Voli Square, 1, Ternopil 46001, e-mail: svkostiv@gmail.com, phone: +380 352524183

Copyright: ( 2016 Pope John Paul II State School of Higher Education in Biała Podlaska. This is an Open Access journal, all articles are distributed under the terms of the Creative Commons Attribution-NonCommercial-ShareAlike 4.0 International (CC BY-NC-SA 4.0) License (http://creativecommons.org/licenses/by-nc-sa/4.0/), allowing third parties to copy and redistribute the material in any medium or format and to remix, transform, and build upon the material, provided the original work is properly cited and states its license. 


\section{Background}

Deep vein thrombosis of lower extremities and pulmonary embolism have common pathogenic roots and are the most common cause of poor blood circulation [2,3]. Several factors that contribute to the development of thrombosis in the venous system are identified $[4,5]$ and must be taken into consideration in the process of preparing for surgery. Despite the usage of sectoral thromboprophylaxis protocols in clinical practice the frequency of postoperative venous thrombosis is high enough [6,7]. In recent years scientists paid attention to non-specific connective tissue dysplasia - a genetically determined pathological condition characterized by defects of fibrous structures and ground substance of connective tissue, which leads to disorders of homeostasis in tissues [1]. In case of surgical treatment multifunction changes in the organs and systems take place including connective tissue; this can create conditions for the development of thrombosis in the venous system.

\section{Materials and methods}

472 patients were examined and operated in departments of surgery of municipal institution of Ternopil regional council "Ternopil University Hospital" in 2010-2014. In the process of surgical treatment thromboprophylaxis was applied according to sectoral protocols [1].

The level of endothelial dysfunction was studied by definition of concentration of endothelin-1, D-dimer and von Willebrand factor.

Coagulation system changes were evaluated by the level of fibrinogen, fibrin stabilizing factor, thromboplastic activity and plasma recalcification time.

According to the risk scale of venous thromboembolic complications suggested by J. Caprini [7] low risk of the venous thromboembolic events was found in 158 (33.47\%) patients, moderate risk - in 131 (27.75\%) patients, high risk - in 117 (24.79\%) and very high risk - 41 (8.69\%) patients.

In the postoperative period a thrombotic process in the system of IVC was diagnosed in $96(20.34 \%)$ patients. The incidence of postoperative thrombosis in the IVC system was directly related to the risk level of the venous thromboembolic complications. Thus, in patients with very high and high risk for venous thromboembolic complications according to the J. Caprini scale the development of postoperative thrombosis was observed in 47 cases (25.68\%), in patients with moderate risk - in 30 observations (22.90\%), and in patients with low risk - in 19 observations (12.03\%).

Nonspecific connective tissue dysplasia was diagnosed in 51 (53.13\%) cases out of 96 patients with postoperative thrombosis in the IVC system. The vast majority of them (65.6\%) were patients who had been operated with a high level of surgical stress. In this group of patients there were revealed the clinical signs of nonspecific connective tissue dysplasia; in 27 (45.1\%) observations an asthenic type of constitution was detected, in 18 (36.6\%) - hypermorbid syndrome, in 31 (57.7\%) - varicose veins (class C1 - 27 cases, class C2 - 14 cases). In the process of laboratory assessment of indicators of metabolic products in a connective tissue the level of total oxyproline exceeded the reference value by $41.77 \%$ ( $p<0.001)$, free oxyproline - by $46.85 \%$ ( $p$ $<0.001)$, and bound oxyproline - by $31.71 \%(\mathrm{p}<0.001)$.

\section{Results and discussion}

Determining of the level of endothelial dysfunction and the state of hemocoagulation system was performed during the preoperative, intraoperative and postoperative phases of the treatment process of 472 patients. Postoperative venous thrombosis in the IVC system was diagnosed in 96 (20.34\%) patients, 51 (53.13\%) of whom were diagnosed with non-specific connective tissue dysplasia. These patients are characterized by higher levels of endothelial dysfunction and hypercoagulable state in comparison with other patients irrespective of the degree of surgical stress to which they were assigned. 
Table 1. Endothelial dysfunction in patients with non-specific connective tissue dysplasia

\begin{tabular}{|c|c|c|c|}
\hline Indicator & $\begin{array}{c}\text { Endothelin-1, } \\
\text { pg / ml }\end{array}$ & $\begin{array}{c}\text { D-dimer, } \\
\mathrm{ng} / \mathrm{ml}\end{array}$ & $\begin{array}{c}\text { von Willebrand factor, } \\
\%\end{array}$ \\
\hline Norm & $6.51 \pm 0.17$ & $244.74 \pm 1.74$ & $151.02 \pm 1.23$ \\
\hline Preoperative phase & $\begin{array}{l}7,69 \pm 0,07 \\
(\mathrm{p}<0.001)\end{array}$ & $\begin{array}{c}267,84 \pm 1.13 \\
(p<0.001)\end{array}$ & $\begin{array}{c}162.22 \pm 0.98 \\
(p<0.001)\end{array}$ \\
\hline Intraoperative phase & $\begin{array}{l}8.31 \pm 0.07 \\
(p<0.001)\end{array}$ & $\begin{array}{c}273.87 \pm 1.12 \\
(p<0.001)\end{array}$ & $\begin{array}{c}179.17 \pm 1.18 \\
(\mathrm{p}<0.001)\end{array}$ \\
\hline 3 hours after surgery & $\begin{array}{l}9.31 \pm 0.08 \\
(p<0.001)\end{array}$ & $\begin{array}{c}337.52 \pm 2.04 \\
(p<0.001)\end{array}$ & $\begin{array}{c}192.38 \pm 0.81 \\
(p<0.001)\end{array}$ \\
\hline 6 hours after surgery & $\begin{array}{l}9.05 \pm 0.09 \\
(\mathrm{p}<0.001)\end{array}$ & $\begin{array}{c}312.11 \pm 1.34 \\
(p<0.001)\end{array}$ & $\begin{array}{c}187.86 \pm 0.94 \\
(p<0.001)\end{array}$ \\
\hline
\end{tabular}

In the process of analysis of the indicators of endothelial dysfunction it was found that preoperative levels of endothelin-1, D-dimer and von Willebrand factor exceeded values in patients without non-specific connective tissue dysplasia, respectively, by $18.13 \%, 9.44 \%$ and $7.42 \%(p<0.001)$. The intraoperative phase was marked by increase of their level. Maximum values of growth parameters were set on the $3 \mathrm{~d}$ hour after the operation. In this period of time the indicator of endothelin-1 was 1.4 times bigger $(\mathrm{p}<0.001)$ than its level of the preoperative period, D-dimer - was 1.3 times bigger $(\mathrm{p}<0.001)$, and von Willebrand factor $-1,2$ times bigger $(\mathrm{p}<0.05)($ Table 1$)$.

Surgery and the development of endothelial dysfunction initiate the formation of hypercoagulation syndrome in the patients undergoing surgery. Preoperative level the indicators of coagulation system in patients of the selected group exceeded the indicators obtained in patients without non-specific connective tissue dysplasia. Thus, the content of fibrinogen in blood serum exceeded the level of patients without non-specific connective tissue dysplasia by $37.1 \%(\mathrm{p}<0.001)$, fibrin stabilizing factor - by $22.1 \%(\mathrm{p}<0.05)$ thromboplastic activity by $17.8 \%(p<0.05)$ and plasma recalcification time - by $26.6 \%(p<0.001)$. Significant growth of indicators of coagulation system was registered in the intraoperative phase of the investigation. Maximum values were reached on the $3 \mathrm{~d}$ hour of postoperative period.

Thus, the content of fibrinogen in the blood serum was bigger than the preoperative value in 1.8 times (p $<0.001)$, fibrin stabilizing factor - in 1.5 times ( $p<0.001)$, thromboplastic activity - in 1.3 times $(p<0.001)$, plasma recalcification time - in 1.2 times $(\mathrm{p}<0.05)$ (Table 2).

Table 2. Coagulation system in patients with non-specific connective tissue dysplasia

\begin{tabular}{|c|c|c|c|c|}
\hline Indicator & $\begin{array}{c}\text { Fibrinogen, } \\
\text { g / l }\end{array}$ & $\begin{array}{c}\text { Fibrin stabilizing } \\
\text { factor, } \\
\mathbf{s} \\
\end{array}$ & $\begin{array}{c}\text { Thrombo-plastic } \\
\text { activity, } \\
\% \\
\end{array}$ & $\begin{array}{c}\text { Plasma recalcifica- } \\
\text { tion time, } \\
s \\
\end{array}$ \\
\hline Norm & $3.77 \pm 0.05$ & $42.02 \pm 0.85$ & $50.21 \pm 0.50$ & $110.15 \pm 0.61$ \\
\hline Preoperative phase & $\begin{array}{l}5.17 \pm 0.06 \\
(p<0.001)\end{array}$ & $\begin{array}{c}51.30 \pm 0.95 \\
(p<0.001)\end{array}$ & $\begin{array}{c}59.17 \pm 0.75 \\
(p<0.001)\end{array}$ & $\begin{array}{c}139.52 \pm 1.91 \\
(p<0.001)\end{array}$ \\
\hline Intraoperative phase & $\begin{array}{l}7.41 \pm 0.08 \\
(p<0.001)\end{array}$ & $\begin{array}{l}67.19 \pm 0.92 \\
(\mathrm{p}<0.001)\end{array}$ & $\begin{array}{c}73.29 \pm 1.12 \\
(p<0.001)\end{array}$ & $\begin{array}{c}148.37 \pm 1.42 \\
(p<0.001)\end{array}$ \\
\hline 3 hours after surgery & $\begin{array}{l}9.21 \pm 0.08 \\
(p<0.001)\end{array}$ & $\begin{array}{c}76.21 \pm 1.32 \\
(\mathrm{p}<0.001)\end{array}$ & $\begin{array}{c}78.25 \pm 1.00 \\
(p<0.001)\end{array}$ & $\begin{array}{c}155.06 \pm 1.23 \\
(p<0.001)\end{array}$ \\
\hline 6 hours after surgery & $\begin{array}{l}8.74 \pm 0.10 \\
(p<0.001)\end{array}$ & $\begin{array}{c}72.22 \pm 1.55 \\
(\mathrm{p}<0.001)\end{array}$ & $\begin{array}{c}76.22 \pm 1.02 \\
(p<0.001)\end{array}$ & $\begin{array}{c}151.14 \pm 1.45 \\
(\mathrm{p}<0.001)\end{array}$ \\
\hline
\end{tabular}

The obtained results of investigation of coagulation system at different stages of the surgical process point at increased susceptibility to thrombosis in patients with signs of non-specific connective tissue dysplasia. The proof of this is the increase of soluble fibrin monomer complexes during the operational process (Fig. 1). 


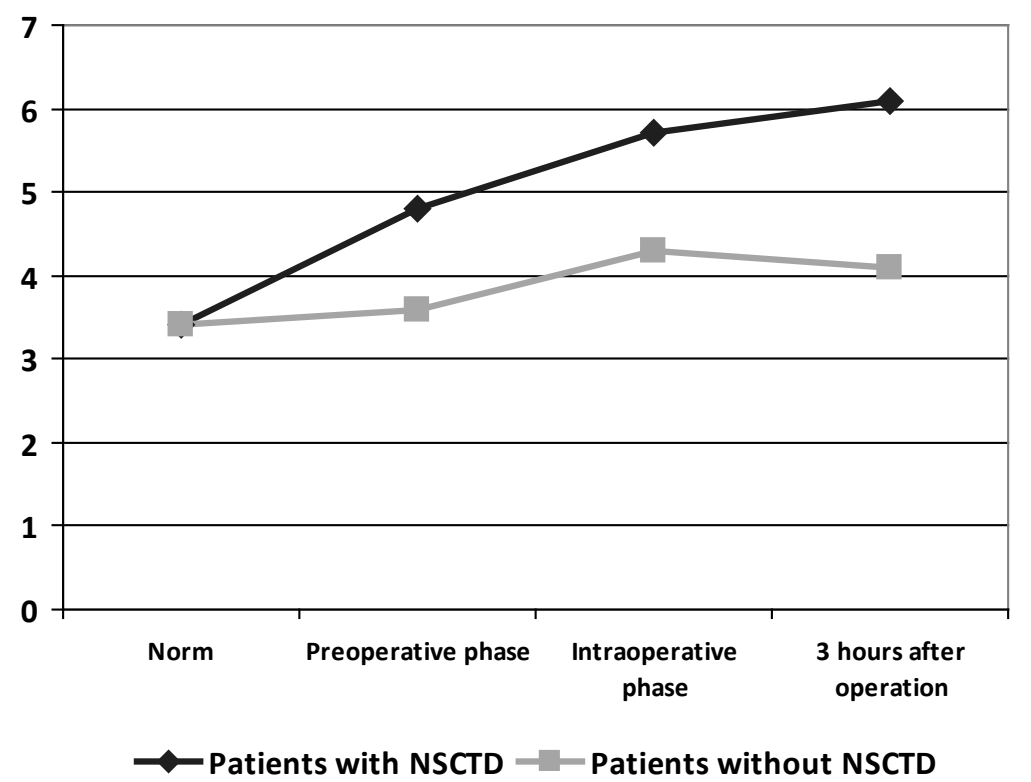

Figure 1. Comparative dynamics of changes of the concentration of soluble fibrin monomer complexes

In the surgical patients with clinical and laboratory signs of connective tissue dysplasia in preoperative period are increased level of endothelial dysfunction, coagulation system of hemostasis and firyn monomer soluble complexes. The maximum activation of these indicators recorded at the end of surgery and in the first hours of the postoperative period. Identified changes determine an increased risk of postoperative venous thrombosis in this cohort of patients.

Having analyzed the obtained results of investigation of coagulation system in patients with non-specific connective tissue dysplasia, it is arguable that the changes of the hemocoagulation system that are in process during surgery - the formation of hypercoagulation syndrome affected by the collapse of fibrinolytic element lead to the creation of conditions for developing of venous thrombosis in VCI system.

To bold among the surgical patients a specific group of patients with signs of non-specific connective tissue dysplasia are appropriate for the development of postoperative venous thromboembolic complications. This division contributes to a more detailed approach to thromboprophylaxis in the postoperative period.

\section{Conclusions}

Non-specific connective tissue dysplasia in surgical patients is characterized by a high degree of endothelial dysfunction and tension of a coagulative element of a coagulation system, which can be considered to be a significant factor in the development of postoperative thrombotic process in the system of the inferior vena cava.

\section{References:}

1. Caprini JA, Thrombotic Risk Assessment: A Hybrid Approach. Available from: http://www.venousdisease. com/Publications/JACaprini-HybridApproach3-10-05.pdf

2. Becattini C, Casazza F, Forgione C, Porro F, Fadin BM, Stucchi A, et al. Acute pulmonary embolism: external validation of an integrated risk stratification model. Chest. 2013; 144-153.

3. Bokareev IN, Popova IN, Kondrateva LV. Venous thromboembolism: treatment and prevention. Surgery. 205; 1: 44-52.

4. Chernucha LM. Deep vein thrombosis. From pathogenesis to treatment. Klinichna flebologiya. 2011; 1: 113116.

5. Gillette BP, DeSimone LJ, Trousdale RT, Pagnano MW, Sierra RJ. Low Risk of Thromboembolic complications with tranexamic acid after primary total hip and knee arthroplasty. Clin Orthop Relat Res. 2013; 471: 150.

6. Vardanyan AV. Postoperative venous thromboembolism - a real danger and modern methods prophilactik. Angiology and Vascular Surgery. 2008; 1: 67-72.

7. Potapov MP, Staver MP. Clinical and laboratory criteria of a non-specific connective tissue dysplasia as a predictor of recurrence of varicose disease of the lower extremities minutes. Phlebology. 2013; 4: 25-31. 